\title{
Civic Learning: A Sine Qua Non of Service Learning
}

\author{
Robert G. Bringle ${ }^{1 * t}$ and Patti H. Clayton ${ }^{1,2 \dagger}$ \\ ${ }^{1}$ Center for Service and Learning, Indiana University Purdue University Indianapolis, Indianapolis, IN, United States, ${ }^{2} \mathrm{PHC}$ \\ Ventures, Cary, NC, United States
}

Civic learning is an essential element of service learning, but one that is often underdeveloped in practice. This article surveys various conceptualizations of civic learning that are in use in higher education around the world, discusses approaches to designing service learning courses to generate civic learning outcomes, and proposes two methods for assessing student attainment of them. The intent is to build instructors' capacities to cultivate the knowledge, skills, dispositions, and behaviors that lie at the very heart of civic learning and of public life in the ever-more complex and interconnected 21st century.

Keywords: service learning, civic learning, course design, assessment, civic engagement, student learning

\section{OPEN ACCESS}

Edited by:

Heidi L. Hallman,

University of Kansas, United States

Reviewed by: Cheryl Dean1dean1keen, Walden University, United States Karon LeCompte,

Baylor University, United States

*Correspondence: Robert G. Bringle rbringle@iupui.edu

${ }^{+}$These authors have contributed equally to this work

Specialty section: This article was submitted to Teacher Education, a section of the journal

Frontiers in Education

Received: 15 September 2020 Accepted: 29 January 2021 Published: 23 March 2021

Citation: Bringle RG and Clayton PH (2021) Civic Learning: A Sine Qua Non of Service Learning.

Front. Educ. 6:606443. doi: 10.3389/feduc.2021.606443

\section{INTRODUCTION}

Virtually all definitions of service learning implicate, if not explicitly name, civic learning as one of the categories of learning outcomes the pedagogy can and should be designed to generate (Furco and Norvell, 2019), including many from North America (e.g., Bringle and Clayton, 2012; Taylor et al., 2015; Clayton and Kniffin, 2017), Europe (e.g., Aramburuzabala et al., 2019; Europe Engage, n.d.), Asia (e.g., Xing and Ma, 2010; Ma, 2018), South America (e.g., Tapia, 2012; Centro Latinoamericano de Aprendizaje y Servicio Solidario, n.d.), and Africa (e.g., Pacho, 2019). We acknowledge that the terms "civic learning" and "civic outcomes" are concepts deeply embedded in American frameworks for, operationalizations of, and analyses of service learning and civic education (Torney-Purta et al., 2015; Hatcher et al., 2017; Hemer and Reason, 2017). Alternative terms that express the other- or public-oriented learning goals intended by the term civic learning are used in discussions of service learning and other forms of curricular and cocurricular civic education in the United States and around the world, including social responsibility, knowledge and skills for democracy, values clarification, moral development, public good, citizenship, democratic competences, sense of solidarity, ubuntu, commitment to and capacities to advance social justice, civic identity, cosmopolitan citizenship, life purpose, and global citizenship. Each of these terms has attributes that overlap with the term civic learning, and each has attributes that are unique to its nature, context, and uses. We use civic learning as an umbrella term to encompass this rich and ever-expanding set of learning outcomes, and we believe it can provide a strong rationale for adopting service learning as well as guidance in designing, implementing, and assessing the learning generated by the pedagogy. Regardless of how civic learning is defined, theorized, and operationalized, it is our conviction that civic learning is a sine qua non-an essential, defining characteristic - of service learning. Although its civic learning potential is by no means the only answer to the question "Why do we need service learning in the curriculum?", our position is that service learning presents a powerful, perhaps even the best, pedagogical opportunity for students to achieve civic learning outcomes. 
Why should we care about civic learning? In addition to faculty and staff, there is evidence that students, funding agencies, community members, civic leaders, higher education executive leaders, and quality assurance frameworks are demonstrating increased attention to the public purposes of higher education. Employers value civic outcomes among the graduates they hire as much or more than they do disciplinebased learning outcomes. A survey commissioned by the Association of American Colleges and Universities confirmed that employers look for attributes such as the following in prospective employees: civic knowledge and skills, intercultural competence, problem solving skills, communication skills, teamwork skills, understanding of cultural diversity, applied knowledge, ethical decision making, and critical thinking skills (Hart Research Associates, 2013). These are all outcomes that transcend academic majors, that are related to civic learning, and that can be strengthened through well-designed service learning.

At the global level, the importance of civic learning is reflected in the aspiration of the United Nations Special Rapporteur Singh's (2016) report on education:

The 1998 World Declaration on Higher Education for the Twenty-First Century: Vision and Action ... called upon higher education institutions to give the opportunity to students to fully develop their own abilities with a sense of social responsibility, educating them to become full participants in democratic society and promoters of changes that will foster equity and justice (para 109).

In the United States, Newman's (1985) assertion that "The advancement of civic learning ... must become higher education's most central goal" rests on the contemporary relevance of the academy's "original purpose of preparing graduates for a life of involved and committed citizenship" (p. xiv). The value of civic learning might also be articulated as a necessary aspect of or complement to professional education (Sullivan, 2005). Matthews (1995), for example, asked, "Why do we need more than a vocational education?" and he suggests as an answer, "In part, because we live more than a vocational life: we live a larger civic life and we have to be educated for it" (p. 70).

Despite such expressions of the value of civic learning, however, it is an underdeveloped aspect of higher education in general and, ironically, of service learning in particular, at least as we have encountered it throughout the United States and around the world. Part of the difficulty is due to the conflation of service learning with volunteerism or with other community-based pedagogies and to the prevalence of an underlying technocratic paradigm. Service learning is not volunteering as part of a course. Unless this is clearly understood, it is too easy to simply add service hours to a syllabus and not integrate the experience of partnering with community members carefully into the overall teaching and learning process so as to generate any learning, much less specifically civic learning. Furthermore, service learning is conceptually distinct from other forms of experiential learning in that they historically have not by definition included an explicit civic learning component as has service learning. Internships, work integrated learning, applied learning, community research, field work, and clinical experiences typically emphasize pre-professional preparation and perhaps personal growth more so than civic-related learning goals. Civic learning can be included in the mix of learning goals associated with these pedagogies-indeed, this is increasingly happening, as in the case of civic internships and justice-oriented clinical education (Bringle, 2017). Too often, however, service learning is thought to be just another community-based pedagogy and is not viewed as, much less designed and implemented as, an inherently "civic" pedagogy that should be designed to generate civic learning along with, and sometimes integrated with, academic and other learning goals.

This article surveys various conceptualizations of civic learning, discusses approaches to designing service learning courses to generate civic learning outcomes, and proposes two methods for assessing those outcomes. Rather than positing one definition of civic learning, we highlight many with the intent that instructors can identify one or more civic constructs that fit their purposes, discipline/profession, and context (e.g., institutional, national, historical, linguistic, political). Thus, this article is intended to stimulate instructors and their co-educators (e.g., community partners, students) to identify and more clearly articulate civic learning objectives, improve the design of a service learning course to reach those outcomes, and incorporate strategies for assessing civic learning. Although our primary focus is on higher education, much if not all of what we discuss is relevant to service learning, other pedagogies, and co-curricular civic programs with civic learning objectives in pre-collegiate, and continuing studies contexts. Action civics is an example of a framework that has been developed for K-12 civic learning (http://actioncivicscollaborative.org).

\section{FRAMEWORKS FOR CIVIC LEARNING}

The multiplicity of definitions of civic learning is a strength of service learning: The variety allows the tailoring of pedagogical design to specific civic learning objectives as they are understood and valued across the full range of settings in which the pedagogy is implemented, whether within a single campus or across the world. Thus, we agree with Furco and Norvell (2019) who reviewed various lists of essential elements of service learning and stated, "while there are fundamental definitions, elements, and principles of service learning that apply no matter what the situation or context, the cultural fiber of the societies in which [it] is practised will ultimately shape [its] overall character" (p. 32). We contend that civic learning is one of those essential elements and that its nature depends on context. Jackson (2019) pointed out that some particular possibilities for civic learning outcomes are taboo topics in some national contexts but work well in other settings. She noted, for example, that generally moral education is avoided in public higher education in the United States and that politics and patriotism are often seen as problematic topics in Hong Kong. In addition, she suggested that in countries where political dissention is not tolerated, civic education may 


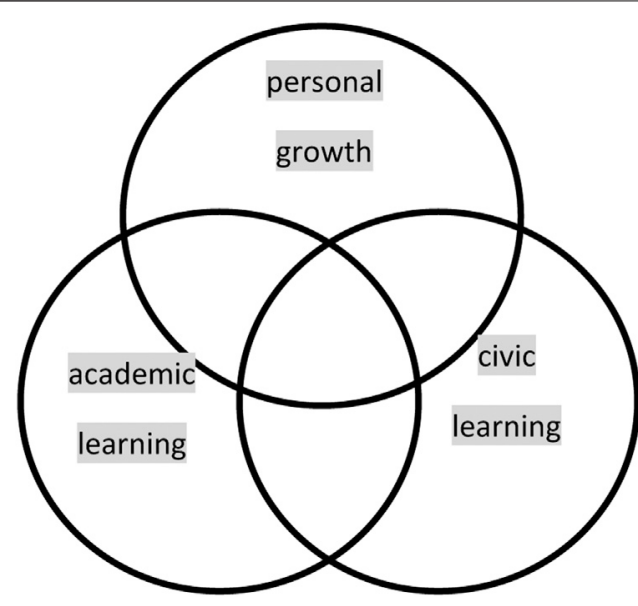

FIGURE 1 | Categories of learning in service learning.

be viewed as a means of promoting conformity and maintaining the status quo, and those deviating, even in the name of justice, may risk sanctions.

This appreciation for the contextualized nature of civic learning should not be viewed as an endorsement of ambiguity with regards to what civic learning means in any particular course. Rather, precision in defining civic learning outcomes is extremely important to the integrity of the pedagogical ecosystem that encompasses course design, implementation, reflection, and assessment (Stokamer and Clayton, 2017). Regardless of the constraints on conceptualizing civic learning that arise due to contextual factors, service learning can be significantly enhanced when the full range of co-educators contributing to teaching and learning develop civic learning goals, clearly articulate them as specific learning objectives, design the pedagogy to generate that learning, assess the extent to which that learning is achieved, and critically examine and refine courses to ensure their fidelity to the selected meanings of civic learning.

Jackson (2019) noted that civic education involves learning to live together within and across society and in relationship with others; it encompasses what people learn about human social life and about relations, duties, identities, loyalties, connections, and the world at large. This type of definition of civic learning is laudable but is very general and not useful to educators who want to design pedagogies to achieve specific civic learning objectives. Frameworks with more precision have greater utility because they identify learning domains within which learning objectives can then be articulated.

As illustrated in Figure 1 service learning is widely understood to include three defining categories of learning: academic learning, personal growth, and civic learning. These categories are both stand-alone and interdependent. Thus, civic learning may be understood to be distinct from academic learning and personal growth and to overlap with either or both of these other categories (Stokamer and Clayton, 2017; Bringle et al., 2016). For example, leadership may be a topic in a course and students can analyze how their community experiences and the civic nature of leadership are related to academic research, findings, and theories (i.e., the intersection of academic learning and civic learning). Alternatively, students can examine examples of civic leadership that they encounter in their community-engaged activities in order to develop an appreciation for how civic leadership is enacted in communities (e.g., in government, in communitybased organizations, in nonprofit organizations) (i.e., civic learning). Alternatively, students can examine their own approaches to leadership, how they appraise their own leaderships skills (e.g., strengths, weaknesses, alternative approaches), how they learn about and develop their own leadership skills, and how they can engage in collaborative leadership in communities in the future (i.e., personal civic growth). The strongest learning potential may exist when civic learning objectives are supported by, connected to, and aligned with the intersection of all three learning categories.

Presumably, in any service learning course, there can be multiple civic learning objectives that are part of the learning experience and each of these can draw upon different sources of learning, either separately (i.e., some learning objectives are independent of the academic content, some are not) or sequentially during a semester (i.e., students analyze a civic learning objective with regard to different academic content during the semester, different community-based experiences over time, and different insights into their own growth). As instructors consider which civic learning objectives are appropriate for their service learning course, they can consider how these three domains (i.e., academic content, service activities, and critical reflection activities) can stimulate civic learning for students. In addition, how any civic learning objective is achieved will be dependent upon how reflection activities promote students developing and deepening their understanding of their learning associated with the objective.

Generally, frameworks for civic learning contain some combination of the following components that instructors seek to cultivate in their students: beliefs, knowledge, attitudes, values, skills, behavioral intentions, and behaviors. Chapters in Hatcher et al. (2017) analyzed civic outcomes from various disciplinary and intellectual perspectives: social psychology, political theory, educational theory, philanthropic studies, well-being, critical theory, and boundary zones. The authors of each chapter surveyed existing theoretical perspectives and generated key questions to guide future inquiry into the role of service learning in contributing to student civic learning outcomes as conceptualized within each of these perspectives. The volume is not exhaustive in its coverage of theoretical perspectives on civic learning, and analyses of and frameworks for civic learning from other disciplines have also been developed (e.g., religious studies, Devine et al., 2002; sociology, Follman, 2015; economics, McGoldrick et al., 2000; science, Newman et al., 2016; other disciplines and professions, Zlotkowski, 2000). In this section, we summarize several prominent frameworks for civic learning with the intention of helping instructors to identify civic learning outcomes that might be relevant to their service learning courses and contexts.

\section{Battistoni's Disciplinary Frameworks}

Battistoni (2002, 2013) acknowledged that most of the discussions and analyses of civic learning at that time were 
anchored in the social sciences. Associated frameworks for civic learning included: constitutional citizenship (individual rights, voting), which is most aligned with political science, law, and policy studies; communitarianism (being a good neighbor, advancing the common good), which is allied with philosophy, religious studies and social work; participatory democracy (being an active participant in public life), which is often found in education and political science courses; public work (co-creating community objects that are of public value), which is linked to political science, public administration, and some professional disciplines; and social capital (membership in associations of civil society), which is aligned with sociology and not-for-profit management majors.

His major contribution was to develop distinct conceptions of civic learning that serve as frameworks outside the social science disciplines. Civic professionalism is particularly applicable to the professional disciplines (e.g., business, engineering, law, architecture). The fundamental ideas are developed in Sullivan's (2005) "Work and Integrity" in which the professions are viewed as having a covenant with society, and professional training and work generate responsibility for the professional to give back to society. Thus, professional work is viewed as having a civic purpose, not simply one of accruing personal benefits. Service learning in such disciplines, then, requires asking the questions, "What does it mean to be a civically-oriented business person?" and "What does it mean to be a civically-oriented lawyer?"

Social responsibility is also applicable to professions (e.g., health, computer science, business) as it explicitly links to professional activities through such organizations as Physicians for Social Responsibility and Business for Social Responsibility. This orientation connects the professions with broader social issues and political knowledge (e.g., inequities in health care). Social justice orientations to civic learning emphasize the solidarity between the individual and broader communities in order to address injustices. Critical service learning (Mitchell, 2008) and criticality as a learning goal (Stokamer and Clayton, 2017) reflect the emphasis on systemic analysis of injustices, awareness of how personal choices may support systems of injustice, and issues related to power and oppression. A social justice orientation to civic learning is particularly salient at faithbased institutions (e.g., Catholic, Jesuit) and is particularly dominant in the southern hemisphere (Tapia, 2012). Developing social justice learning objectives can enrich any service learning course and is well-aligned with those in religious studies, philosophy, and social work.

The ethic of care builds upon the intellectual foundations of connected knowing (e.g., Belenky et al., 1997) as a means of moving from personal orientations to learning to more civic and community-oriented ways of viewing learning and its implications (e.g., social, political, organizational). The ethic of care is especially relevant to gender studies, nursing, and psychology. Public leadership, from a civic perspective, emphasizes collaborative leadership that encompass community building and servant leadership (Frick and Spears, 1996). Service learning courses in management, leadership studies, and public affairs can build upon these understandings of leadership and contrast them with traditional, hierarchical, and power-oriented views.

The framework of the public intellectual is well aligned with the humanities, arts, and literature and involves developing the civic impact of writers, artists, poets, and thinkers on social issues. Their concern for and contributions to civic discourse, discussions, public works, and commentary highlight the relevance of their work beyond the individual. Public scholarship orients research, analysis, and scholarship toward social issues so as to deepen understanding, mobilize action, and inform decision making in a way that involves and supports communities. This type of civic learning may be particularly relevant to journalism, communication studies, sociology, and psychology.

Battistoni $(2002,2013)$ noted that there is a set of skills that transcends any one particular framework of civic learning. These skills include political knowledge and critical thinking, communication skills, public problem solving, civic judgment, civic imagination and creativity, collective action, coalition building, and organizational analysis. Service learning experiences can be designed to facilitate the development of these overarching skills as part of or in addition to any particular other civic learning objectives.

\section{Council of Europe}

The Council of Europe's (2016) Competences for Democratic Culture provided a framework for civic learning that consists of 20 competencies categorized into a) values, b) attitudes, c) skills, and d) knowledge and critical understanding. Values include human dignity, cultural diversity, democracy, and social justice. Attitudes encompass openness to cultural otherness, respect, civic-mindedness, responsibility, selfefficacy, and tolerance of ambiguity. Civic skills consist of learning, analytical and critical thinking, listening and observing, empathy, flexibility, communication, cooperation, and conflict resolution. Civic knowledge and critical understanding can be of self; of language and culture; or of the world's politics, law, human rights, cultures, religions, or history. This framework can provide guidance in designing service learning for democratic citizenship, especially through the explicit incorporation of intercultural dialogue. Intercultural dialogue is defined by the Council of Europe as "an open exchange of views, on the basis of mutual understanding and respect, between individuals or groups who perceive themselves as having different cultural affiliations from each other" (pp. 20-21). The Council published a second monograph (2017) on pedagogy, which identified service learning as one of the means of developing these competencies.

\section{Confucian Five Relationships}

$\mathrm{Ma}$ et al. (2018) provided an historical analysis of moral education and Chinese philosophical traditions and related them to service-learning as it is being explored and developed in China. Five relationships are viewed as fundamental to the spirit of service, social justice, and the welfare of persons who are disadvantaged: benevolence (i.e., caring for others), justice (i.e., justice that serves the common good), propriety 
(i.e., social norms and order), wisdom (i.e., understanding of others and society), and integrity (i.e., trustworthiness and honesty in dealing with others). These "form the core of Chinese ethics, social values, and personal conduct" (p. 29) and can serve as a framework for conceptualizing civic learning.

\section{Association of American Colleges and Universities: Civic Engagement VALUE Rubric}

The Civic Engagement VALUE Rubric is one of 16 rubrics collaboratively developed in the United States to provide guidance for developing criteria for evaluating learning outcomes (https://www.aacu.org/value-rubrics). As with any well-designed rubric, it articulates domains of learning and can thus function as a framework for conceptualizing civic learning. The Civic Engagement VALUE Rubric focuses on how students view their public lives as members of communities. The components of the rubric include: diversity of communities and cultures (including self-awareness and attitude change), analysis of knowledge (connections between academic studies and civic issues), civic identity and commitment (evidence of past activities and future commitment), civic communication (with others to produce civic action), civic action and reflection (initiative, team leadership, insights), and civic contexts and structures (collaborative work within communities to achieve civic aims). Each of these five domains of learning can be parsed into specific civic learning objectives.

\section{Civic-Minded Graduate}

The construct of civic-mindedness was developed to integrate various conceptualizations of civic learning. It is defined as "a person's inclination or disposition to be knowledgeable of and involved in the community, and to have a commitment to act upon a sense of responsibility as a member of that community" (Steinberg et al., 2011, p. 20). The Civic-Minded Graduate (CMG; Bringle and Steinberg, 2010; Bringle et al., 2011; Steinberg et al., 2011; Bringle et al., 2019; Bringle and Wall, 2020) is a construct that integrates personal identity, civic experiences, and educational experiences; it refers to "a person who has completed a course of study (e.g., bachelor's degree), and has the capacity and desire to work with others to achieve the common good" (Bringle and Steinberg, 2010, p. 429). The CMG construct (http://scholarworks.iupui.edu/handle/1805/2667) is composed of ten domains: a) knowledge of volunteer opportunities, b) academic knowledge and technical skills, c) knowledge of contemporary social issues, d) communication and listening skills, e) appreciation of and sensitivity to diversity, f) skills to build consensus, g) valuing community engagement, h) self-efficacy, i) social trustee of knowledge, and j) intentions to be personally involved in community service (Steinberg et al., 2011, p. 22). These domains of CMG are viewed as being common across many service learning courses, and there is evidence that supports their coherence (Bringle et al., 2011; Bringle et al., 2019; Bringle et al., 2020).

\section{Intercultural Competence}

Service learning typically involves students interacting with individuals who are different from them in some ways. Even for domestic service learning, but particularly for international service learning, having learning objectives that are focused on knowledge, skills, attitudes, and behaviors that encompass dialogue across difference, collaboration, humility, cross-cultural understanding, and effective communication is both important and feasible. Deardorff and Edwards (2013) presented the following domains of intercultural competence as representing a consensus of the perspectives of many scholars: attitudes (respect, openness, curiosity/discovery), knowledge (cultural self-awareness, culture-specific knowledge, deep cultural knowledge, socio-linguistic awareness), skills (observing, listening, evaluating, analyzing, interpreting, relating), internal outcomes (flexibility, adaptability, empathy, ethnorelative perspective), and external outcomes (effective and appropriate behavior, communication).

\section{UNESCO's Framework for Global Citizenship}

Some views of civic learning transcend any single national context so as to avoid the charge of being too narrow, divisive rather than inclusive, and potentially ethno-centric (Brooks and Holford, 2009). Replacing a nationally-oriented approach with a global perspective on civic learning can reflect the multiple levels of identities individuals hold (i.e., local, regional, national, global). As one example, UNESCO's (2015, p. 16) delineation of global citizenship aims to enable learners to:

- develop an understanding of global governance structures, rights and responsibilities, global issues and connections between global, national, and local systems and processes;

- recognise and appreciate difference and multiple identities, e.g., culture, language, religion, gender, and our common humanity, and develop skills for living in an increasingly diverse world;

- develop and apply critical skills for civic literacy, e.g., critical inquiry, information technology, media literacy, critical thinking, decision-making, problem solving, negotiation, peace building and personal and social responsibility;

- recognise and examine beliefs and values and how they influence political and social decision-making, perceptions about social justice and civic engagement;

- develop attitudes of care and empathy for others and the environment and respect for diversity;

- develop values of fairness and social justice, and skills to critically analyze inequalities based on gender, socioeconomic status, culture, religion, age, and other issues;

- participate in, and contribute to, contemporary global issues at local, national, and global levels as informed, engaged, responsible and responsive global citizens. 


\section{United Nations' Sustainable Development Goals}

The United Nations (https://www.undp.org/content/undp/en/ home/sustainable-development-goals.html) proposed 17 interconnected Sustainable Development Goals (SDGs) as a "a call for action by all countries-poor, rich and middleincome-to promote prosperity while protecting the planet." The SDGs represent a "universal call to action to end poverty, protect the planet and improve the lives and prospects of everyone, everywhere." Although not themselves a conceptualization of civic learning, the SDGs do provide a framework for focusing service learning activities in areas such as responsible production and consumption, education, gender equality, affordable and clean energy, environmental issues, and reduced inequality. Civic learning objectives can be developed within or across one or more of the SDGs. For example, the Commonwealth Secretariat (Osman et al., 2017) developed a Curriculum Framework related to the SDGs, offering it as a "guide for countries to conceptualise, review or further develop their national curricula and ensure that education is integral to any strategy to create a resilient generation that will advocate for action and the attainment of the SDGs in a holistic, integrated manner" (p. iii). "Core competencies" named in the Curriculum Framework as being relevant to all of the SDGs include (pp. 8-9):

- Envisioning-being able to imagine a better future

- Critical thinking and reflection-learning to question our current belief systems and to recognise the assumptions underlying our knowledge, perspectives, and opinions

- Systemic thinking-acknowledging complexities and looking for links and synergies when trying to find solutions to problems.

- Building partnerships-promoting dialogue and negotiation, learning to work together, so as to strengthen ownership of and commitment to sustainable action through education and learning.

- Participation in decision making-empowering oneself and others.

Derived from these core competencies are a set of "integrated competencies" (p. 11) that are categorized into three domains: a) Knowledge and Understanding (e.g., multiple literacies; social, environmental, and economic challenges and complexities), b) Skills and Applications (e.g., analysis, fact finding, observing, independent learning, planning), and c) Values and Attitudes (e.g., sense of purpose and hope, resilience, adaptability, commitment to justice). The Curriculum Framework also includes further specification of learning objectives within these three domains for each of the 17 SDGs. The Curriculum Framework can be found in its entirety at https://www. thecommonwealth-educationhub.net/wp-content/uploads/2017/ 01/Curriculum_Framework_for_SDGs_July_2017.pdf.

\section{ARTICULATING CIVIC LEARNING OUTCOMES}

Any one of the civic domains in these frameworks warrants more specific adaptation to each particular context. For example, growth in students' self-efficacy would be tailored to the particular course (e.g., self-efficacy with regard to advocacy directed toward a particular group of stakeholders on a specific public issue). There are likely to be several civic learning objectives in a course that span academic content, civic growth, and personal growth, and each civic learning objective should be developed and clearly articulated by one or more of the partners (i.e., community partners, students, instructor).

Table 1 contains questions from Musil (2015) that can help instructors explore current and additional civic learning outcomes that might be relevant to their service learning course. Like Battistoni, Musil started with a position that the discipline/profession can provide a basis for exploring civic learning objectives, some of which are embedded in the discipline and, alternatively, some of which need to be added to the discipline. Her prompts challenge instructors to examine the landscape of their discipline/profession for possible civic learning objectives. This can be an enriching curricular development activity for, as Huber and Hutchings (2018) noted, "when faculty from different disciplinary communities teach their fields wearing a civic lens, both the concept of citizenship and even the field itself (as taught and learned) are subject to change" (p. x).

However, the discipline or profession is but one starting point for generating and articulating civic learning goals. Frameworks such as those summarized above provide additional sources of ideas for instructors to draw on when they are considering what civic learning objectives are appropriate for a service learning course. Further elaboration of a civic learning objective can be undertaken collaboratively with community partners and students.

For example, an instructor might be integrating service learning into an environmental science course in order to enhance students' skills in advocating for environmental stewardship. The nature of that environmental stewardship objective might be modified or clarified by community partners and students, but it originates primarily with the instructor. Alternately, it may be that the leaders or staff of a community organization come into the partnership with a course having already determined their own civic learning goals for anyone they work with. In a service learning course in which the community-engaged activities are project based, a community partner may add an advocacy component to the students' activities in order to help them understand policy issues associated with the activities and the importance of systemic analysis of the social issue beyond the project itself. As a specific example, a social justice and animal welfare organization in North Carolina seeks to cultivate three capacities in anyone who 
TABLE 1 | Civic prompts excerpted from Musil (2015).

What is civic about or related to your course content or your discipline?

Which of these civic capabilities does your disciplinary domain especially embrace?

Or put another way, which are associated as outcomes for your disciplinary domain?

How might the learning capabilities that your disciplinary domain is deeply committed to suggest ways to frame a set of civic inquiries and actions that embed such civic learning easily for all students within your discipline?

What are some big civic issues that are common to your disciplinary domain or course that lend themselves to civic inquiry or civic actions?

What various civic angles on the issues do you raise in your courses?

What responses/outcomes do you expect from students?

What additional issues might acquire greater prominence within your domain if civic inquiry were given priority?

Write down any of the civic learning outcomes that flow from your course or discipline, either from the lists provided or from your own experience/knowledge.

partners with them: cultural humility, empathy, and systems critique (Hensley et al., 2018).

Similarly, students who shape and participate in community-engaged activities may articulate civic learning goals before beginning a project, either on their own or in partnership with community members and faculty. Once the project is underway, they may also demonstrate civic learning outcomes that were unanticipated by any of the partners. Thus, civic learning objectives may also be generated organically from the cumulative and emergent experiences of students, the instructor, and community partners. They may also be developed collaboratively with other stakeholders, such as individuals in leadership positions on campus (e.g., dean, director, chair) so that they too understand what learning is being aspired to, why, and how it will enhance the educational experiences of students.

\section{DESIGNING SERVICE LEARNING COURSES FOR CIVIC LEARNING OUTCOMES}

Only after civic learning outcomes have been articulated can a service learning course be deliberately designed or revised to generate those outcomes and other learning objectives. There may be civic learning outcomes that are unique to each student due to background, context, community-engaged activities, or community partners. For example, demographic diversity within and across classrooms and communities highlight the "double consciousness" that may be experienced by students who identify closely with members of the communities with whom they are partnering. Hickmon (2015) contains reflections by a Black student at a predominantly white institution that generally provides service to minority communities. Also, students who are experiencing such challenges as geographic dislocation, housing or food insecurity, loss of significant family relationships, or cultural barriers may find their own levels of meaning and civic learning. Thus, instructors need to consider the prospect of both unique and shared learning outcomes. However, the use of the service learning as a pedagogy does presume that some civic learning outcomes are viewed as central to the purposes of the service learning course and should be common for all students. Then the following question can begin to be answered: "What specific aspects of your course are or can be designed to generate particular student civic learning outcomes?"

Stokamer and Clayton (2017) presented a case for the interconnected nature of three primary course components: a) service, b) academic activities, and c) critical reflection. None of these stands alone, and course design to achieve civic learning outcomes must embody a systems approach in which these components of the service learning course are "mutually reinforcing and equally necessary for civic competence" (Stokamer, 2011, p. 67). In this section we provide an overview of the civic learning potential of each of these three components. The community-engaged activities, the setting for those activities, the community members with whom the students are interacting, and the historical, cultural, political, and economic contextual factors can all contribute to the process of deepening civic learning in a service learning course. Stokamer and Clayton (2017) suggested that instructors "be guided by their civic learning goals when collaboratively determining service tasks" (p. 52). The community-engaged activities might involve a) direct service, b) indirect service, c) collaborative research, or d) advocacy for social change (Bringle et al., 2016). However, it may be that all service activities are not well-suited to support a particular civic learning outcome. Boyle-Baise (2002) noted, "A charitable task probably will not generate insights for social change" (p. 33). Stokamer and Clayton explained that

although critical reflection can generate learning of a particular concept through examination of an experience in which the concept is notably absent, service is generally designed to immerse learners in settings, processes, and interactions in which the concept in question is present and can be critically examined. Students may thus be well positioned to compare and contrast diverse worldviews ... through service tasks that enlist their capacity to listen or document, such as through co-producing oral histories with community members ... [and] to build such civic skills as giving and receiving constructive feedback and to develop civic identities as cogenerators of knowledge [through service that takes the form of community-engaged research]. (p. 52)

Bringle and Clayton (2012) similarly explored the ways in which reciprocal partnerships "lend themselves readily to civic learning, variously defined," suggesting that when students are 
co-creators of the work of the partnership "they are well positioned to learn about teamwork, project management, leadership, and communication ... [and] to transform their sense of identity and of agency as civically oriented persons" (p. 116). Stokamer and Clayton (2017) further suggested that "Both the nature of academic activities and their content can be designed through the lens of civic learning goals" (p. 53). Readings, videos, reports, podcasts, websites, artwork, and music can be carefully selected to both introduce diverse worldviews and provide information related to the public issues the service learning partnership addresses. The authors noted "academic activities in and beyond the classroom can ... provide firsthand experience with and opportunities to examine dynamics related to ... civic learning goals." Activities such as non-traditional speakers, debates, role playing, and team-based civic problem-solving activities, for example, can all be designed to "help participants determine and problematize the conditions under which they do and do not tend to listen attentively to unfamiliar or contrary perspectives" (p. 54).

Neither service nor academic activities on their own, however, generate civic (or any other) learning without the integration of critical reflection on those activities that has been designed specifically to facilitate meaning making in accordance with the learning objective. Critical reflection is the component of service learning (and any form of experiential learning) that generates, deepens, and documents learning and improves the quality of practice, partnerships, and inquiry. Whitney and Clayton (2011) suggested that intentional design of critical reflection happens at two levels: the overall strategy (which includes when and where it occurs, who participates, how and by whom feedback is provided) and the specific mechanisms that compose that strategy (which consist of prompts that are clearly aligned with learning objectives to guide reflective meaning making, whether in written, oral, digital, artistic, or embodied formats). "A critical reflection strategy designed such that all partners are, at one time or another, involved-as learners, in developing prompts, in giving and receiving feedback-may provide otherwise missed opportunities for civic learning" according to Stokamer and Clayton (2017, pp. 55-56).

The DEAL model of critical reflection is an example of a structure for the design of critical reflection mechanisms in any format (or mix of formats) - individual, collaborative, written, oral, digital, etc.- to generate civic (and other) learning goals (Ash and Clayton, 2009). DEAL is a customizable, researchgrounded model in which the prompts support learners in Describing their experiences, Examining them using prompts specifically linked to learning goals, and then Articulating Learning in a way that leads to enhanced future action and learning (specifically, by answering four questions: What did I learn? How did I learn it? Why does this learning matter? What will I do in light of it?). Depending on the particular civic learning goals of interest, Examine prompts such as the following might be used (Whitney and Clayton, 2011; Bringle and Clayton, 2012):

- What was I/someone else trying to accomplish? In taking the actions I/they did, was the focus on symptoms or underlying causes? Was the focus (symptom or cause) appropriate to the situation? How might $\mathrm{I} /$ they focus more on underlying causes in the future?

- What roles did each person/group/organization involved in the situation play and why? What alternative roles could each have played? Did I/other individuals act unilaterally or collaboratively and why? Should I/they have worked with others in a different way?

- In what ways did differentials in power and privilege emerge in this experience? What are the sources of power and privilege in this situation, and who benefits and is harmed? How might any inappropriate dependencies be eliminated?

- What is in the interest of the common good in this situation? In what ways is the individual good (mine/others) linked to and/or contrary to the common good? What trade-offs between them are involved? In what way did any other trade-offs (long-term/short-term, justice/efficiency, etc.) emerge in this situation? Who made the trade-offs? Were the trade-offs made appropriate or inappropriate and why?

- How do other members of this community define such concepts as "community" and "service"? What cultural, historical, political, and other factors help explain these definitions and the impact they do or could have in this particular situation?

Norris et al. (2017) explored critically reflective digital storytelling as a particularly powerful type of critical reflection mechanism that "has the potential to be a particularly civic approach to critical reflection" because it "leverages the power of story to both bring to the surface and problematize dominant ways of thinking and acting and capitalizes on the potential of the digital environment to enable and connect private and public dialogue and meaning-making" (p. 178). Stith et al. (2018) provided guidance for designing critical reflection especially in the context of critical service learning to support examination of issues associated with justice and injustice (Table 2). Any of these prompts can provide a basis for problematizing and potentially shedding a technocratic orientation (e.g., "We are here to help you solve your problem.") and can help instructors, students, and community partners explore some of the civic issues implicated in their collaborative community engagement. Bringle et al. (2016) presented sets of DEAL prompts for various combinations of personal growth, academic learning, and civic learning.

Research that investigates the relationships between particular design choices in each of these three arenas (service, academic activities, critical reflection) is needed in order to produce and continually refine evidence-based guidance for instructional design that is intended to generate specific civic learning outcomes. As one starting point, Stokamer and Clayton (2017) suggested inquiry that positions civic learning as both the dependent variable-examining the factors that influence student attainment of any particular civic learning outcomes-and the independent variable-examining the influence particular conceptions of civic learning have on the design of service, academic activities, and critical reflection. Battistoni (2013) encouraged similar research into design issues at the program or curricular level to determine, as one example, whether "a sustained, developmental, cohort-based 
TABLE 2 | Critical service learning prompts excerpted from Stith et al. (2018).

Examine whether/how their service work addresses root causes of social problems.

Understand the connection between their service experiences and civic life, public policy, and social systems.

Examine their preconceptions about social problems, community, or citizenship with which they entered the course.

Understand the ethical challenges that arise during the service experience.

Recognize the strengths of the community in which they work.

Consider current interventions to the social problem and explore alternative solutions.

curricular approach to service learning [is] better able to produce, over time, persons with stronger measures on all of the indicators of civic knowledge, skills, identity, and motivation, among other categories?" (p. 126).

\section{ASSESSING CIVIC LEARNING}

Because there is no one definition of civic learning, there can be no one method, procedure, or instrument for assessing civic learning. With the exception of civic knowledge, the vast majority of approaches to assessing civic learning outcomes have taken the form of self-report measures such as surveys (Torney-Purta et al., 2015; Hemer and Reasons, 2017). A survey is simply an interview that is conducted on paper and it can provide phenomenologically meaningful information. Self-reports are indirect measures of civic learning outcomes, as are peer evaluations and reports from community partners. However, indirect measures can suffer from a social desirability response set, inaccurate recall of past behaviors, inaccurate predictions of future behaviors, cognitive biases, and inaccurate accounts of causal phenomenon (Dunning et al., 2004; Bowman and Seifert, 2011; Kolek, 2013).

Direct measures that encompass demonstrated performance and learning provide some advantages over self-report and avoid some of their limitations. Examples of direct assessment include examinations, written products evaluated with rubrics, and observations of skills and behaviors evaluated with rubrics. Multiple choice examinations typically assess a particular type of learning (descriptive knowledge) and may not adequately capture higher order cognitive processing or the nuances of civic learning that can be generated in a service learning course.

This raises the question of the purpose of the assessment. At the most general level, assessment can communicate learning objectives to students and others when the goals of assessment are shared prior to conducting it. Formative assessment can provide feedback to students before final products are submitted and to instructors about how well the course is progressing. Summative assessment can be a basis for grading and for communicating to others (e.g., department chairs, executive institutional leaders, future students, community partners) the value of the service learning experiences. There may be purposes for assessment beyond the course, for example when a curriculum is being assessed, when institutional quality assurance is being documented, as part of grant-supported activities, and when research is being undertaken. The nature of assessment needs to be tailored to its purpose.

Bringle et al. (2013) suggested that, in addition to issues such as these that apply to virtually all assessment of student learning, assessment of civic learning (and diversity and global learning) raises additional considerations. One of these is the question of whose voices are included in the assessment process, which is particularly salient given the democratic, co-creative aspirations of service learning. Broad participation in establishing the civic learning goals, determining the nature of meaningful evidence of their attainment, and gauging the quality of learning helps "ensure that assessment is shaped by and is useful to multiple constituencies within and beyond the academy" (p. 5). Another issue that arises in the context of assessing civic learning in particular is that such learning is often intended to be transformative in nature, meaning that "it may develop over extended periods of time, across multiple courses, and in a variety of contexts," a set of conditions that may require "developmentally designed and integrated strategies that depend on collaboration across multiple teaching and assessment contexts" (pp. 5-6).

A variety of approaches to assessing civic learning have been developed, two of which we describe here. They were selected because they are research-grounded, cover a range of civic learning outcomes, and are applicable not only in service learning courses but also as part of any pedagogy that seeks to cultivate civic learning and co-curricular programs that have civic learning objectives (Bringle et al., 2011; Bringle et al., 2020). The DEAL model, which integrates critical reflection and assessment, lends itself to assessing any civic (or other) learning objectives. As noted above, the CMG framework, in contrast, encompasses multiple pre-established elements of civic learning and is therefore most useful when one or more of them matches a learning objective in the course. We encourage service learning practitioners to build on these and to develop and share additional approaches to assessing civic learning.

\section{DEAL Framework for Assessment}

The DEAL model for critical reflection provides a basis not only for structuring reflection prompts but also for assessing the learning generated and deepened through critical reflection. There are two types of rubrics associated with DEAL, both of them relevant to civic learning (Ash and Clayton, 2009). The first lays out four levels of critical thinking for each of several critical thinking standards (adapted from Paul and Elder, 2001), including, for example, accuracy (supporting claims with evidence), breadth (considering multiple perspectives), and fairness (representing others' ideas with integrity). This rubric has a corollary feedback tool that explains each of the standards of critical thinking and provides questions to ask oneself or one's learners to help strengthen each standard (e.g., accuracy: How do I know this? breadth: Is there another way to interpret what this means?). Several of the frameworks summarized above include critical thinking as an important civic learning goal. 
TABLE 3 | Example Bloom-based rubrics for select civic learning goals.

\begin{tabular}{|c|c|c|c|c|c|c|}
\hline Learning Goal & 1 (Identify) & 2 (Explain) & 3 (Apply) & 4 (Analyze) & 5 (Synthesize) & 6 (Evaluate) \\
\hline $\begin{array}{l}\text { Students will } \\
\text { understand the } \\
\text { complexities of } \\
\text { relationships between } \\
\text { individual rights and the } \\
\text { common good }\end{array}$ & $\begin{array}{l}\text { Defines } \\
\text { "individual } \\
\text { interests/rights" } \\
\text { and "common } \\
\text { good" }\end{array}$ & $\begin{array}{l}\text { Explains "individual } \\
\text { interests/rights" and } \\
\text { "common good" in my } \\
\text { own words so that } \\
\text { someone unfamiliar with } \\
\text { these concepts would } \\
\text { understand them }\end{array}$ & $\begin{array}{l}\text { Provides an example of } \\
\text { the presence or absence } \\
\text { of "individual interests/ } \\
\text { rights" and "common } \\
\text { good" in a particular } \\
\text { situation }\end{array}$ & $\begin{array}{l}\text { Compares (similarities) and } \\
\text { contrasts (differences) what } \\
\text { an "individual interests/rights" } \\
\text { focus might prioritize in this } \\
\text { situation with what a } \\
\text { "common good" focus might } \\
\text { prioritize }\end{array}$ & $\begin{array}{l}\text { Proposes at least two } \\
\text { potential resolutions of the } \\
\text { tension between "individual } \\
\text { interests/rights" and } \\
\text { "common good" in this } \\
\text { situation }\end{array}$ & $\begin{array}{l}\text { Evaluates these potential } \\
\text { resolutions in terms of their } \\
\text { long-term consequences and } \\
\text { justifies my judgment as to the } \\
\text { most appropriate resolution } \\
\text { accordingly }\end{array}$ \\
\hline Learning Goal & 1 (Identify) & 2 (Explain) & 3 (Apply) & 4 (Analyze) & 5 (Evaluate) & 6 (Synthesize) \\
\hline $\begin{array}{l}\text { Students will } \\
\text { understand the } \\
\text { complexities of access } \\
\text { to power }\end{array}$ & $\begin{array}{l}\text { Identifies } \\
\text { multiple } \\
\text { sources of } \\
\text { power }\end{array}$ & $\begin{array}{l}\text { Explains these sources of } \\
\text { power in my own words } \\
\text { such that others who are } \\
\text { not familiar with them can } \\
\text { understand them }\end{array}$ & $\begin{array}{l}\text { Provides examples of the } \\
\text { presence and absence of } \\
\text { these sources of power in } \\
\text { the context of my service- } \\
\text { learning project (i.e., Who } \\
\text { is and is not using power } \\
\text { from which sources?) }\end{array}$ & $\begin{array}{l}\text { Compares (similarities) and } \\
\text { contrasts (differences) the } \\
\text { access of the various } \\
\text { stakeholders in my project to } \\
\text { each of these sources of } \\
\text { power } \\
\text { AND considers what } \\
\text { processes enable and hinder } \\
\text { access } \\
\text { AND considers the } \\
\text { consequences of that access } \\
\text { on the situation overall and on } \\
\text { the stakeholders }\end{array}$ & $\begin{array}{l}\text { Critiques the access to } \\
\text { these sources of power } \\
\text { sources in this situation in } \\
\text { terms of equity (i.e., should } \\
\text { it be changed and why? } \\
\text { What trade-offs would be } \\
\text { required to change it?) }\end{array}$ & $\begin{array}{l}\text { Produces an alternative set of } \\
\text { processes to enhance equity } \\
\text { in access to these and/or } \\
\text { additional sources of power in } \\
\text { this situation }\end{array}$ \\
\hline
\end{tabular}

The second type of rubric uses Bloom's (1956) Taxonomy to structure indicators for up to six levels of learning. This structure is used to generate rubrics for learning goals in any category, whether academic learning, personal growth, or civic learning. See Table 3 for example rubrics for two potential civic learning goals.

\section{Civic Minded Graduate Framework for Assessment}

Steinberg et al. (2011) presented three different methods for assessing civic-mindedness as conceptualized in the construct of the CMG: a) a CMG Scale, which is comprised of 30 self-report items; b) a CMG narrative prompt, which produces a written narrative that is scored with a rubric; and c) a CMG interview protocol, which produces a transcript that is scored with a rubric. Generally, these three assessment strategies demonstrated convergence in measuring CMG (Steinberg et al., 2011).

The self-report measure of CMG has received extensive validation as a measure of civic-mindedness. Steinberg et al. (2011) found that responses on the CMG Scale were correlated with Morton's (1995) construct of integrity. Morton viewed integrity as the degree to which civic values and civic behaviors are aligned with and integrated with the self. Bringle and Wall (2020) found correlations between identity as a student and $\mathrm{CMG}$, civic identity and CMG, CMG and all of the motives for volunteering on the Volunteer Functions Inventory (Clary et al., 1998), and CMG and measures of interest in charity, service programs, and advocacy types of service. Bringle et al. (2019) found that CMG was related to openness to diversity, selfefficacy, both social change and charity orientations to service, and endorsing the principle of care. In addition, they found CMG to be correlated with non-prejudicial attitudes and selfconfidence for social behaviors.
Although the CMG Scale might be relevant to assessment at the program level and in research, in order to obtain alternative direct evidence of civic-mindedness, the following prompt was developed and students were asked to write a response:

I have a responsibility and a commitment to use the knowledge and skills I have gained as a college student to collaborate with others, who may be different from me, to help address issues in society.

Please indicate the extent to which you agree or disagree with this statement by circling the appropriate number.

Strongly Agree 123456 Strongly Disagree

Considering your education and experiences as a college student, explain the ways in which you agree or disagree with this statement and provide personal examples when relevant. (Steinberg et al., 2011, p. 23)

The rating scale was included to prime the respondent's thinking about the issues raised in the prompt before writing a response. A rubric for scoring written responses was developed that focuses on the degree to which written narratives reflect civic identity, understanding of social issues, participation in society, collaboration across differences, and the benefit of education to address social issues (the rubric can be accessed at http://hdl. handle.net/1805/2667).

\section{ISSUES RELATED TO CIVIC LEARNING}

Service learning has helped civic learning become more visible as a category of learning for educators and students. It is a relatively new and unfamiliar pedagogy to many academics and presents challenges with regard to learning goals, design, and assessment. 
Civic learning in particular raises additional issues. One set of challenges involves the push back that may come from some colleagues who believe that "civic learning is not my job" or, indeed, an appropriate function of higher education at all. Promoting and enhancing civic learning may not need to be everyone's responsibility. However, it is desirable that most if not all members of the academy understand why some instructors take civic learning seriously, why some courses warrant identifying and cultivating civic learning objectives, how service learning enriches the learning environment in ways that are empirically supported as effective (e.g., active learning, collaborative learning, meaningful learning), how civic learning contributes to significant learning across the curriculum, how service learning promotes authentic relationships that benefit communities, and how service learning results in desirable outcomes for students in their future lives, including careers. Such shared understanding, if not buy-in, raises the likelihood that instructors will be better supported in using innovative pedagogical approaches to a broader and deeper set of learning goals. Slowly, around the world, there is increasing appreciation for the contribution that service learning as a pedagogy and civic learning as a category of learning can make to the public purposes of higher education (e.g., Xing and Ma, 2010; Tapia, 2012; Ma, 2018; Aramburuzabala et al., 2019; Pacho, 2019).

Any civic learning objective raises the issue of the complexity of its scope or range of focus. Does it encompass a local, national, and/ or global scale? Jackson (2019) noted that locally-oriented perspectives on social issues may be more natural, intuitive, efficient, and easier for educators and students. However, this perspective runs the risk of being clannish, filial, and alienating others as being different or irrelevant. Focusing on the national level of a social issue can be more challenging because of its scale and intra-national variability. It can also be complicated by issues related to individuals' identities as residents in multiple nationstates, their (and the state's) complicated mix of desires for and concerns about both assimilating and retaining the distinctiveness of cultural heritages, competing loyalties and sense of duty, and the sometimes incompatible priorities between national and other (e.g., regional, state, local) levels of governance and allegiance. Service learning courses may immerse students in experiences that challenge their status quo. On the other hand, service learning may have the potential to provide new meaning and purpose to their lives and provide a basis for improving well-being, trust, and connectedness (Konrath, 2016; Stukas et al., 2016).

The 2020 pandemic and the increasing use of technology in education raise interesting prospects for transforming the nature of service learning through reimaging, redefining, and redesigning many key aspects of the pedagogy (Bringle and Clayton, 2020). How are "communities" constituted in a digital and technologically interconnected world? How are "relationships" established and maintained via technological means, and how do virtual relationships contribute to learning and collaboration? How can "service" activities occur in a digital world? How can "reflection" take different forms using technology? And, most central to the current topic, how might the meaning of "civic" change in virtual contexts? What does it mean to be civic in a virtual world? What new versions of civic knowledge, skills, dispositions, and behaviors are critical to operating in both virtual and physical communities?

Another complexity related to civic learning involves the extent to which democratic engagement is, in fact, the paradigm within which any instance of service learning operates. Pervasive technocratic orientations to education focus on the transfer of knowledge from academicallycredentialed experts (i.e., faculty) and view students and communities alike in terms of deficits and needs (Saltmarsh et al., 2009). Thus, service learning is too often reduced to a focus on the transmission and application of disciplinary knowledge and, if there is any intention to educate students for roles in broader communities, the focus is on the cultivation of "proto-experts who will be able to perform civic tasks in and on communities that they work with because they will have the knowledge and credentials to know what to do to help communities improve" (Saltmarsh et al., 2009, p. 8). Under those conditions, service learning fails to position everyone involved as co-responsible members of communities who collaborate to further their own and one another's knowledge of and capacities for participation, agency, systems critique, and democratic co-creation. It thus tends to minimize, if not neglect entirely, the intentional development of the knowledge, skills, and values encompassed by civic learning understood in other than managerial, bureaucratic, and hierarchical terms. Along these lines, Jackson (2019) points out that education for global citizenship can be approached from a neoliberal perspective that emphasizes meritocracy and competition rather than more cosmopolitan perspectives that emphasize interdependency and common goals. A key to fulfilling the rich and essential civic learning potential of service learning, then, is conceptualizing the pedagogy as democratic civic engagement, which "seeks the public good with the public and not merely for the public as a means to facilitating a more active and engaged democracy" and which "adheres to the shared understanding that the only way to learn the norms and develop the values of democracy is to practice democracy as part of one's education" (Saltmarsh et al., 2009, p. 9 and p. $6)$. It is worth noting that the paradigm of democratic engagement itself generates additional civic learning goals such as the three explored by Stokamer and Clayton (2017, p. 48):

a. inclusivity, which has at its core capacities to think beyond the single perspective of one's own worldview and act accordingly;

b. criticality, which has at its core capacities to recognize and challenge enshrined structural inequities that limit social justice;

c. co-creation, which has at its core capacities to bring an assetbased orientation to collaboration and to integrate the knowledge, perspectives, and resources of all partners in determining the questions to be addressed, possibilities to be pursued, and strategies for collaborating effectively and with integrity. 
Finally, there is the contested issue of how explicitly political service learning courses, civic education, and the other activities of students should be. Hartman (2013) asked practitioners to consider the degree to which service learning avoids confronting the "impossibility of an apolitical democratic civic education" (p. 68). He stated that institutions of higher education and their staff must explicitly articulate their commitment to democratic values (which can include inclusivity, participatory, and fairness; Saltmarsh et al., 2009), lest the normative apolitical stance of technocratic engagement prevail. For some practitioners, it is only when service learning is political that social change is possible. Indeed, it is useful to ask whether "apolitical" service learning ever exists. We acknowledge that context matters in answering these questions and that, in some national settings, politically oriented community engagement activities may be inappropriate, unwise, or possibly dangerous.

\section{CONCLUSION}

Higher education institutions . . . should increase their interdisciplinary focus and promote critical thinking and active citizenship. This would contribute to sustainable development, peace, wellbeing and the realization of human rights. . . . Higher education must not only give solid skills for the present and the future world but must also contribute to the education of ethical citizens committed to the construction of peace, the defense of human rights and the values of democracy. (UNESCO, 2009, p. 2).

\section{REFERENCES}

P. Aramburuzabala, L. McIlrath, and H. Opazo (Editors) (2019). Embedding service learning in European higher education. New York: Routledge.

Ash, S. L., and Clayton, P. H. (2009). Generating, deepening, and documenting learning: the power of critical reflection in applied learning. J. Appl. Learn. Higher Education 1, 25-48.

Battistoni, R. M. (2002). Civic engagement across the curriculum: a resource book for faculty in all disciplines. Boston, MA: Campus Compact.

Battistoni, R. M. (2013). "Civic learning through service learning: conceptual frameworks and research," in Research on service learning: conceptual frameworks and assessment. Editors P. H. Clayton, R. Bringle, and J. Hatcher (Sterling, VA: Stylus), Vol. 2A, 111-132.

Belenky, M. F., Clinchy, B. M., Goldberger, N. R., and Tarule, J. M. (1997). Women's ways of knowing: the development of self, voice, and mind. New York: Basic Books.

Bloom, B. S. (1956). Taxonomy of educational objectives: handbook I. Cognitive domain. Philadelphia, PA: David McKay.

Bowman, N., and Seifert, T. A. (2011). Can college students accurately assess what affects their learning and development? J. Col. Stud. Develop. 52, 270-290.

Boyle-Baise, M. (2002). Multicultural service learning: education teaching in diverse communities. New York, NY: Teachers College Press.

Bringle, R. G. (2017). Hybrid high-impact pedagogies: integrating service-learning with three other high-impact pedagogies. Mich. J. Community Serv. Learn. 24 (1), 49-63. doi:10.3998/mjcsloa.3239521.0024.105

Bringle, R. G., and Steinberg, K. (2010). Educating for informed community involvement. Am. J. Community Psychol. 46, 428-441. doi:10.1007/s10464010-9340-y

Bringle, R. G., Brown, L., Hahn, T. W., and Studer, M. (2020). Pedagogies and civic programs to develop competencies for democratic culture and civic learning outcomes. Bordón. Revista de Pedagogía 71 (3), 27-43. doi:10.13042/Bordon.2019.72003
Service learning is a component of civic engagement in higher education that understands teaching, research and other creative activity, and service (or third mission) as interrelated activities that can be done in collaboration with community partners in ways that benefit and respect communities and that are consistent with the missions of higher education (Bringle et al., 1999; Saltmarsh and Hartley, 2012). As such, the development of service learning courses is not an end in itself but rather a means toward broader public purposes of all types of civic engagement activities. Service learning can be a powerful pedagogy for enhancing academic learning and personal growth, and it can uniquely accentuate the salience of civic learning in higher education and cultivate the knowledge, skills, dispositions, and behaviors that are so crucial to the flourishing of democracy, the advancement of justice, preparation for meaningful careers, and the realization of world peace. Accordingly, it can be a model for democratic approaches to engagement for other activities in the academy (Saltmarsh et al., 2009). For these reasons, improving our understanding of what constitutes civic learning and how civic learning objectives can be achieved and assessed will serve the public purposes of higher education.

\section{AUTHOR CONTRIBUTIONS}

$\mathrm{RB}$ and PC contributed to all aspects of the manuscript.

Bringle, R. G., and Clayton, P. H. (2012). "Civic education through servicelearning: what, how, and why?" in Higher education and civic engagement: comparative perspectives. Editors L. McIlrath, A. Lyons, and R. Munck (New York, NY: Palgrave Macmillan), 101-124.

Bringle, R. G., and Clayton, P. H. (2020). Integrating service learning and digital technologies: examining the challenge and the promise. RIED. Revista Iberoamericana de Educación a Distancia [The Ibero-American J. Digital Education] 23 (1), 43-65. doi:10.5944/ried.23.1.25386

Bringle, R. G., Clayton, P. H., and Plater, W. M. (2013). Assessing diversity, global, and civic learning: A means to change in higher education. Democracy and Diversity. Association of American Colleges and Universities. 13(3), 4-6.

R. G. Bringle, R. Games, and E. A Malloy (Editors) (1999). Colleges and universities as citizens. Needham Heights, MA: Allyn and Bacon.

Bringle, R. G., Hahn, T. W., and Hatcher, J. A. (2019). The civic-minded graduate: additional evidence II. Int. J. Res. Service-Learning Community Engagement 7 (1), 3. doi:10.37333/001c.11481

Bringle, R. G., Reeb, R., Brown, M. A., and Ruiz, A. (2016). Service learning in psychology: enhancing undergraduate education for the public good. Washington, DC: American Psychological Association.

Bringle, R. G., Studer, M. H., Wilson, J., Clayton, P. H., and Steinberg, K. (2011). Designing programs with a purpose: to promote civic engagement for life. J. Acad. Ethics 9 (2), 149-164. doi:10.1007/s10805-011-9135-2

Bringle, R. G., and Wall, E. (2020). Civic-minded graduate: additional evidence. Mich. J. Community Serv. Learn. 26 (1), 1-17. doi:10.3998/mjcsloa.3239521.0026.101

Brooks, R., and Holford, J. (2009). Citizenship, learning, education: themes and issues. Citizenship Stud. 13 (2), 85-103. doi:10.1080/13621020902749027

Centro Latinoamericano de Aprendizaje y Servicio Solidario (CLAYSS) (n.d.). What is "service learning"? Available at: http://www.clayss.org/english/ servicelearning_school.html. (Accessed August 8, 2020).

Clary, E. G., Snyder, M., Ridge, R. D., Copeland, J., Stukas, A. A., Haugen, J., et al. (1998). Understanding and assessing the motivations of volunteers: a functional 
approach. J. Pers Soc. Psychol. 74 (6), 1516-1530. doi:10.1037//0022-3514.74.6. 1516

Clayton, P. H., and Kniffin, L. (2017). An introduction to service-learning and community engagement as co-inquiry. [Blog post]. NC: Elon University.

Council of Europe (2016). Competences for democratic culture: living together as equals in culturally diverse democratic societies. Strasbourg: Council of Europe Publishing.

Council of Europe (2017). Council of Europe reference framework of competences for democratic culture $(C D C)$. Volume 3 - guidance for implementation. 2. $C D C$ and pedagogy. Strasbourg: Council of Europe Publishing.

Deardorff, D. K., and Edwards, K. E. (2013). "Framing and assessing students' intercultural competence in service learning," in Research on service learning: conceptual frameworks and assessment, Vol. 2A: students and faculty. Editors P. H. Clayton, R. G. Bringle, and J. A. Hatcher (Sterling: VA, Stylus), 157-183.

R. Devine, J. A. Favazza, and F. M. McLain (Editors) (2002). From cloister to commons: concepts and models for service learning in religious studies. Sterling, VA: Stylus.

Dunning, D., Heath, C., and Suls, J. M. (2004). Flawed self-assessment: implications for health, education, and the workplace. Psychol. Sci. Public Interest 5, 69-106. doi:10.1111/j.1529-1006.2004.00018.x

Europe Engage (n.d.). Our definition of service-learning. Available at: https:// europeengage.org/our-definition-of-service-learning/ (Accessed August 18, 2020).

Follman, J. (2015). An overlooked lens: applying structuration theory, actornetwork theory, and theories of space to service-learning. The Int. J. Res. Service-Learning Community Engagement 3 (1).

D. M. Frick and L. C. Spears (Editors) (1996). On becoming a servant leader. New York, NY: Wiley.

Furco, A., and Norvell, K. (2019). "What is service learning? Making sense of the pedagogy and practice," in Embedding service learning in European higher education: developing a culture of civic engagement. Editors P. Aramburuzabala, L. McIlrath, and H. Opazo (New York, NY: Routledge), 13-35.

Hart Research Associates (2013). It takes more than a major: employer priorities for college learning and student success. Washington, DC: Association of American Colleges and Universities.

Hartman, E. (2013). No values, no democracy: the essential partisanship of a civic engagement movement. Mich. J. Community Serv. Learn. 19 (2), 58-71.

J. A. Hatcher, R. G. Bringle, and T. W. Hahn (Editors) (2017). Research on student civic outcomes in service learning: conceptual frameworks and methods. Sterling, VA: Stylus.

Hemer, K. M., and Reason, R. D. (2017). "Student civic outcomes in higher education," in Research on service learning and student civic outcomes. Editors J. Hatcher, R. Bringle, and T. Hahn (Sterling, VA: Stylus), 25-43.

Hensley, L., Arrington, A., and Clayton, P. H. (2018). "Beyond judgment, beyond fences [workshop]," in Pathways to Achieving Civic Engagement (PACE) Conference (Elon, NC: United States North Carolina Campus Compact), (February, 2018).

Hickmon, G. (2015). Double consciousness and the future of service-learning. Mich. J. Community Serv. Learn. 22 (1), 86-88.

Huber, M. T., and Hutchings, P. (2018). "Foreword: civic learning: intersections and interactions," in Citizenship across the curriculum. Editors M. Smith, R. Nowacek, and J. Bernstein (Bloomington, IN: Indiana University Press), i-xiii.

Jackson, L. (2019). "Global citizenship: allegiance to what, exactly? Keynote address at educating the global citizen conference," Munich, Germany, (March, 2019).

Kolek, E. A. (2013). Can we count on counting? An analysis of the validity of community engagement survey measures. Int. J. Res. Service-Learning Community Engagement 1 (1), 92-108.

Konrath, S. (2016). "The joy of giving," in Achieving excellence in fundraising. 4th Edn, Editors D. Burlingame, T. Seiler, and G. Tempel (New York, NY: Wiley), 11-26.

$\mathrm{Ma}, \mathrm{C} . \mathrm{H}$. (2018). "The concept and development of service-learning," in Servicelearning as a new paradigm in higher education in China. Editors C. H. Ma, A. C. Chan, A. C. Liu, and F. M. Mak (Lansing, MI: Michigan State University Press), 3-16.

D. H. Ma, A. C. Chan, A. C. Liu, and F. M. Mak.(Editors) (2018). Service-learning as a new paradigm in higher education in China. Lansing, MI: Michigan State University Press.
Mathews, D. (1995). The politics of diversity and the politics of difference: are academics and the public out of sync? Higher Education Exchange, 66-71.

McGoldrick, K., Battle, A., and Gallagher, S. (2000). Service-learning and the economics course: theory and practice. The Am. Economist 44 (1), 43-52. doi:10.1177/056943450004400106

Mitchell, T. (2008). Traditional vs. critical service-learning: engaging the literature to differentiate two models. Mich. J. Community Serv. Learn. 14 (2), 50-65.

Morton, K. (1995). The irony of service: charity, project, and social change in service-learning. Mich. J. Community Serv. Learn. 2, 19-32.

Musil, C. M. (2015). Civic prompts: making civic learning routine across the disciplines. Washington, DC: Association of American Colleges and Universities.

Newman, F. (1985). Higher education and the American resurgence. Stanford, CA: Carnegie Foundation for the Advancement of Teaching.

J. L. Newman, D. W. Sunal, and C. S. Sunal (Editors) (2016). Science and service learning. Charlotte, NC: Information Age Publishing.

Norris, K., Siemers, C., Clayton, P. H., Weiss, A., and Edwards, K. E. (2017). "Critical reflection and civic mindedness," in The Cambridge handbook of service-learning and community engagement. Editors C. Dolgon, T. Eatman, and T. Mitchell (Cambridge, MA: Cambridge University Press), 168-182.

Osman, A., Ladhani, S., Findlater, E., and McKay, V. (2017). Curriculum framework for the sustainable development goals. London: Commonwealth Secretariat.

Pacho, T. (2019). "Service-learning: an innovative approach to education in Africa," in The good education and Africa's future: concepts, issues and options. Editors J. K. Mugo, P. Namubiru-Ssentamu, and M. Njihia (Nairobi: Paulines Publications Africa), 232-259.

Paul, R. P., and Elder, L. (2001). The miniature guide to critical thinking. Tomales, CA: Foundation for Critical Thinking (www.criticalthinking.org).

J. Saltmarsh and M. Hartley (Editors) (2012). To serve a larger purpose. Philadelphia, PA: Temple University Press.

Saltmarsh, J., Hartley, M., and Clayton, P. H. (2009). Democratic engagement white paper. Boston, MA: New England Resource Center for Higher Education.

Singh, K. (2016). Report of the Special Rapporteur on the right to education. Geneva: United Nations Human Rights Council.

Steinberg, K., Hatcher, J. A., and Bringle, R. G. (2011). A north star: civic-minded graduate. Mich. J. Community Serv. Learn. 17 (1), 19-33.

Stith, M., Emmerling, D., and Malone, D. (2018). Critical service-learning conversations tool. Durham, NC: Duke University.

Stokamer, S. T. (2011). Pedagogical catalysts of civic competence: the development of a critical epistemological model for community-based learning. (Doctoral dissertation). Available from ProQuest Dissertations and Theses database. (UMI No. 3468983).

Stokamer, S. T., and Clayton, P. H. (2017). "Student civic learning through service learning: instructional design and research," in Research on service learning and student civic outcomes. Editors J. A. Hatcher, R. G. Bringle, and T. W. Hahn (Sterling, VA: Stylus), 45-65.

Stukas, A. A., Hoye, R., Nicholson, M., Brown, K. M., and Aisbett, L. (2016). Motivations to volunteer and their associations with volunteers' well-being. Nonprofit Voluntary Sector Q. 45 (1), 112-132. doi:10.1177/0899764014561122

Sullivan, W. M. (2005). Work and integrity: the crisis and promise of professionalism in America. 2nd Edn. San Francisco, CA: Jossey-Bass.

Tapia, M. N. (2012). "Academic excellence and community engagement: reflections on the Latin American experience," in Higher education and civic engagement: comparative perspectives. Editors L. McIlrath, A. Lyons, and R. Munck (London: Palgrave), 187-203.

Taylor, A., Butterwick, S., Raykov, M., Glick, S., Peikazadi, N., and Mehrabi, S. (2015). Community service-learning in Canadian higher education. Ottawa: Social Sciences and Humanities Research Council of Canada.

Torney-Purta, J., Cabrera, J. C., Roohr, K. C., Liu, O. L., and Rios, J. A. (2015). Research Report No. RR-15-34. Assessing civic competency in higher education: research background, frameworks, and directions for next generation assessment. (Princeton, NJ: Educational Testing Service).

UNESCO (2009). 2009 World conference on higher education: the new dynamics of higher education and research for societal change and development. Paris: UNESCO.

UNESCO (2015). Global citizenship education: topics and learning objectives. Paris: UNESCO. 
United Nations (nd). Sustainable development goals. Available at: https://www.un. org/sustainabledevelopment/ (Accessed July 18, 2020).

Whitney, B. C., and Clayton, P. H. (2011). "Research on the role of reflection in international service learning," in International service learning: conceptual frameworks and research. Editors R. G. Bringle, J. A. Hatcher, and S. G. Jones (Sterling, VA: Stylus), 145-187.

J. Xing and C. Ma (Editors) (2010). Service-learning in Asia: curricular models and practices. Hong Kong: Hong Kong University Press.

Zlotkowski, E. (2000). Service-learning in the disciplines. Mich. J. Community Serv. Learn. Spec. Issue, 61-67.
Conflict of Interest: The authors declare that the research was conducted in the absence of any commercial or financial relationships that could be construed as a potential conflict of interest.

Copyright (c) 2021 Bringle and Clayton. This is an open-access article distributed under the terms of the Creative Commons Attribution License (CC BY). The use, distribution or reproduction in other forums is permitted, provided the original author(s) and the copyright owner(s) are credited and that the original publication in this journal is cited, in accordance with accepted academic practice. No use, distribution or reproduction is permitted which does not comply with these terms. 